\title{
EFFECT OF REHABILITATION TRAINING ON CRUCIATE LIGAMENT INJURY
}

\author{
EFEITO DE TREINAMENTO DEREABILITAÇÃO EM FERIMENTOS NO LIGAMENTO CRUZADO
}

LERCIC

EFECTO DE ENTRENAMIENTO DE REHABILITACIÓN EN HERIDAS EN EL LIGAMENTO CRUZADO

Original Article

ARTIGO ORIGINAL

Artículo Original

\author{
Chuan Shu' 1 (P) \\ (Physical Education Professional) \\ Liming $\mathrm{Han}^{2}$ (ID \\ (Physical Education Professional) \\ Haochuan Yang ${ }^{1}$ (D) \\ (Physical Education Professional) \\ 1. Sports College, Jiangxi Science \\ and Technology Normal University, \\ Nanchang, Jiangxi, China. \\ 2. College of Physical Education, \\ Xingtai University, Xingtai, Hebei, \\ China.
}

\section{Correspondence:}

Liming Han

Xingtai, Hebei, China. 054001.

hanhanabc@163.com

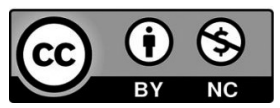

\begin{abstract}
Introduction: Sports injuries in the anterior cruciate ligament of the knee are common and serious in the field of sports and rehabilitation medicine. Objective: To observe the effect of early comprehensive rehabilitation training on knee function recovery after anterior cruciate ligament reconstruction. Methods: 40 patients were randomly divided into observation group $(n=19)$ and control group $(n=21)$. The control group received routine rehabilitation training and the observation group had water exercise added to their intervention. The active knee flexion range, extension range, and Lysholm score were observed before and 3 months after rehabilitation training. Results: 3 months after training, the active knee flexion range and extension range in the observation group were better than those in the control group $(p<0.05)$. Lysholm score in the observation group ( $91.2 \pm 5.6)$ was higher than that in the control group (78.3 \pm 4.8$)$, and the difference was statistically significant $(p<0.05)$. Conclusions: Early systematic rehabilitation training can reduce pain and swelling and improve the function of the knee joint after operation. Level of evidence II; Therapeutic studies - investigation of treatment results.
\end{abstract}

Keywords: Knee Joint; Anterior Cruciate Ligament; Rehabilitation.

\section{RESUMO}

Introdução: ferimentos no ligamento cruzado anterior do joelho são comuns e graves no campo do esporte e da medicina de reabilitação. Objetivo: Observar o efeito de um treino de reabilitação abrangente para recuperar a função do joelho depois de reconstrução do ligamento cruzado anterior. Métodos: 40 pacientes foram divididos aleatoriamente em um grupo observação $(n=19)$ e um grupo controle $(n=21)$. Ambos os grupos receberam treinamento de reabilitação de rotina, e o grupo observação recebeu também um treino com atividades físicas aquáticas. A amplitude da flexão e da extensão do joel ho a tivo e a pontuação na escala de Lysholm foram avaliadas antes do treinamento de reabilitação e três meses depois. Resultados: 3 meses depois do treinamento, a amplitude da flexão e da extensão do joelho ativo no grupo observação estavam melhores que no grupo controle $(p<0,05)$. A pontuação na escala de Lysholm, para o grupo observação $(91,2 \pm 5,6)$, foi maior que para o grupo controle $(78,3 \pm 4,8)$, com diferença estatisticamente significativa $(p<0,05)$. Conclusões: Treino sistemático de reabilitação pode reduzir dor e inchaço e melhorar a função da articulação do joelho após operação. Nível de evidência Il; Estudos terapêuticos - investigação de resultados de tratamento.

Descritores: Articulação do Joelho; Ligamento Cruzado Anterior; Reabilitação.

\section{RESUMEN}

Introducción: heridas en el ligamento cruzado anterior de la rodilla son comunes y graves en el campo del deporte y de la medicina de rehabilitación. Objetivo: Observar el efecto de un entrenamiento de rehabilitación abarcativa para recuperar la función de la rodilla después de reconstrucción del ligamento cruzado anterior. Métodos: Fueron divididos 40 pacientes, de forma aleatoria, en un grupo de observación ( $n=19)$ y un grupo control ( $n=21)$. Ambos grupos recibieron entrenamiento de rehabilitación de rutina, y el grupo observación recibió también un entrenamiento con actividades físicas acuáticas. La amplitud de la flexión y de la extensión de la rodilla activa y la puntuación en la escala de Lysholm fueron evaluadas antes del entrenamiento de rehabilitación y tres meses después. Resultados: 3 meses después del entrenamiento, la amplitud de la flexión y de la extensión de la rodilla activa en el grupo observación estaban mejores que en el grupo control ( $p<0,05)$. La puntuación en la escala de Lysholm, para el grupo observación $(91,2 \pm 5,6)$, fue mayor que para el grupo control $(78,3 \pm 4,8)$, con diferencia estadísticamente significativa $(p<0,05)$. Conclusiones: Entrenamiento sistemático de rehabilitación puede reducir dolor e inflamación y mejorar la función de la articulación de la rodilla después de la operación. Nivel de evidencia II; Estudios terapéuticos - investigación de resultados de tratamiento.

Descriptores: Articulación de la Rodilla; Ligamento Cruzado Anterior; Rehabilitación. 


\section{INTRODUCTION}

Anterior cruciate ligament injury of the knee is a common and serious sports injury of the knee joint, and is a common disease in the field of sports and rehabilitation medicine. ${ }^{1}$ Improper treatment is likely to lead to knee instability, articular cartilage and meniscus injury, and even secondary osteoarthritis, which seriously affects knee functional activities and significantly reduces the quality of life of patients. ${ }^{2}$ At present, arthroscopic ACL reconstruction is commonly used in clinical practice. ${ }^{3}$ Arthroscopic ACL reconstruction is the preferred method for improving instability after $A C L$ fracture, this technology can accurately restore the stability of the knee joint, with the advantages of less surgical trauma, short duration of surgery and quick postoperative recovery. ${ }^{4}$ Effective postoperative rehabilitation training can further consolidate the surgical effect and promote the recovery of knee function, however, non-standard functional exercise will lead to relaxation or elongation or even fracture of the ligament after reconstruction, which will make the ligament unable to play its due function and directly affect the surgical effect. ${ }^{5}$ So early rehabilitation training is very important. Water exercise therapy can improve the rehabilitation effect of knee osteoarthritis. ${ }^{6}$ From August 2013 to September 2015, the rehabilitation department of our hospital performed water exercise intervention on 19 patients after anterior cruciate ligament reconstruction of knee joint, with good results, the report is as follows.?

\section{METHOD}

\section{Object}

Sixty patients who met the inclusion and exclusion criteria were divided into observation group $(n=30)$ and control group $(n=30)$ according to the random number table. 20 patients were dropped off during the study, and 19 patients were actually enrolled in observation group and 21 patients in control group. Observation group: 11 males, 8 females; Age: $20--54$ years old, mean age: $(28.67 \pm 6.37)$ years old; There were 5 cases of traffic accident injury, 6 cases of high fall and 8 cases of sports injury. Acute injury in 12 cases, old injury in 7 cases; 11 cases were reconstructed with autogenous tendon and 8 cases with allogeneic tendon. Control group: 12 males and 9 females; The average age was (27.67 \pm 5.37$)$ years. There were 7 car accidents, 6 high falls and 8 sports injuries. Acute injury in 13 cases, old injury in 8 cases; 11 cases were reconstructed with autogenous tendon and 10 cases with allogeneic tendon. There was no significant difference in general data between the two groups ( $P>0.05)$, indicating comparability.

\section{Rehabilitation methods}

\section{The control group}

Routine rehabilitation training was adopted, that is, nurses assisted rehabilitation therapists to exercise patients' affected limbs. At the initial stage of rehabilitation training (2----4 weeks after surgery), knee flexion training was performed in sitting position, and the range of motion of knee joint was maintained from 0 to 110. $15 \mathrm{~min} /$ time, 2 times/day, lasted until discharge; Muscle strength training, straight leg raising, stopping and lowering training, $15 \mathrm{~min} /$ time, 2 times/day, continued until discharge. In the middle stage of rehabilitation training (5-8 weeks after surgery), the initial training method of rehabilitation training was continued, and the range of motion of knee joint was maintained at 0-120. 6 weeks after the operation, squatting exercise was started, 15 min/time, twice/day, and continued until discharge. Proprioceptive training was increased 8 weeks after the operation, such as power bicycle riding (15-20 rain/ time, 2 times/day), balance instrument exercise (15-20 min/time, 2 times/ day), and continued until discharge. Later stage of rehabilitation training (9 weeks after surgery and before discharge), life function training, such as washing face, eating, toilet training; Strengthening joint stability training, such as up and down jump training, lateral jump training, 15"--20 min/time, 2 times/day, continued until discharge. Supplementary physical therapy, such as continuous passive activity meter of knee joint, low-frequency therapy only and wax therapy, was given from the beginning of the training, and 1 to 2 kinds of supplementary physical therapy were selected every day, with a total of 20 rain each time, twice per day, until the discharge. ${ }^{8}$

\section{Observation group}

Water exercise was added to the control group.

\section{Method of underwater movement}

Water sports to the affected limb training. Underwater sitting knee holding exercise (suitable for the early stage of rehabilitation training) : Generally passive buckling angle is greater than $90^{\circ}$, active buckling up to $90^{\circ}$, gradually reaching the passive buckling Angle of $110^{\circ} \sim$ $120^{\circ}$, active flexion reached 110 , underwater resistance training of knee bend was performed 40 times/set, 3 times/day, and continued until discharge. Parallel bar training (suitable for early rehabilitation training) : Step by step, one-leg weight bearing training, center of gravity transfer training, walking training, walking speed $<60$ steps/ rain, walking for 3-5 min/time, 3 times/day, until discharge. Water training (suitable for the middle and late stage of rehabilitation training), such as lower limb drafting, squat, heel raising, lateral knee flexion and extension when standing on one foot, and squat on one leg, was performed for 3-5 min/time, 3 times/day, and lasted until discharge. Water jumping and swimming training (suitable for the middle and later stages of rehabilitation training) : Water jumping, up and down 3-5 min/time, 3 times/d, lasted until discharge; Swimming training was performed according to the patient's usual swimming style, 5 to $10 \mathrm{~min}, 3$ times a day, and continued until discharge. The water exercise process follows the principle of step by step, from easy to difficult, from passive to active, and the training intensity should be acceptable to patients. ${ }^{9}$

\section{RESULTS}

The comparison of Lysholm score, active knee flexion range and active knee extension range between the two groups before and after rehabilitation training is shown in Table 1.

Comparison of knee function recovery between the two groups before and after training. Before training, there was no statistical significance in Lysholm knee score and knee flexion and extension between the two groups ( $P>0.05)$. After training, Lysholm knee score and knee flexion and extension in both groups were significantly higher than before training, and the observation group was higher than the control group, the difference was statistically significant $(P<0.05)$. (Table 2)

Table 1. Comparison of postoperative VAS scores between the two groups.

\begin{tabular}{c|c|c|c|c}
\hline Group & Preoperative & Postoperative 3 d & T & P \\
\hline The control group & $7.57 \pm 1.41$ & $5.43 \pm 1.32$ & 6.609 & 0.000 \\
\hline Observation group & $7.62 \pm 1.36$ & $4.28 \pm 1.15$ & 10.721 & 0.000 \\
\cline { 1 - 3 } $\mathrm{t}$ & 0.140 & 3.598 & \multicolumn{2}{|}{} \\
\cline { 1 - 3 } $\mathrm{p}$ & 0.445 & 0.000 & & \\
\cline { 1 - 3 }
\end{tabular}

Table 2. Comparison of knee function recovery between the two groups before and after training.

\begin{tabular}{c|c|c|c}
\hline Group & Time & Knee score & Knee flexion and extension \\
\hline \multirow{2}{*}{$\begin{array}{c}\text { The control } \\
\text { group }\end{array}$} & Before the training & $42.36 \pm 5.18$ & $16.07 \pm 2.83$ \\
\cline { 2 - 4 } & After the training & $62.65 \pm 7.61$ & $46.55 \pm 6.13$ \\
\hline $\begin{array}{c}\text { Observation } \\
\text { group }\end{array}$ & Before the training & $42.67 \pm 6.03$ & $16.69 \pm 3.12$ \\
\cline { 2 - 4 } & After the training & $75.77 \pm 6.82$ & $69.25 \pm 7.87$ \\
\hline
\end{tabular}


The lateral knee flexion angle of 3 patients with anterior cruciate ligament reconstruction was selected as a statistical index, and the changes before and after rehabilitation training were shown in Figure 1 and Figure 2.

\section{DISCUSSION}

The repair and reconstruction of anterior cruciate ligament injury has always been an important research topic in the field of orthopedics and sports trauma, because postoperative patients often suffer from knee pain, edema and knee dysfunction, if not timely treatment and treatment, will lead to a series of sequelae. Studies have shown that the load added to the ACL during rehabilitation is actually not very large, and

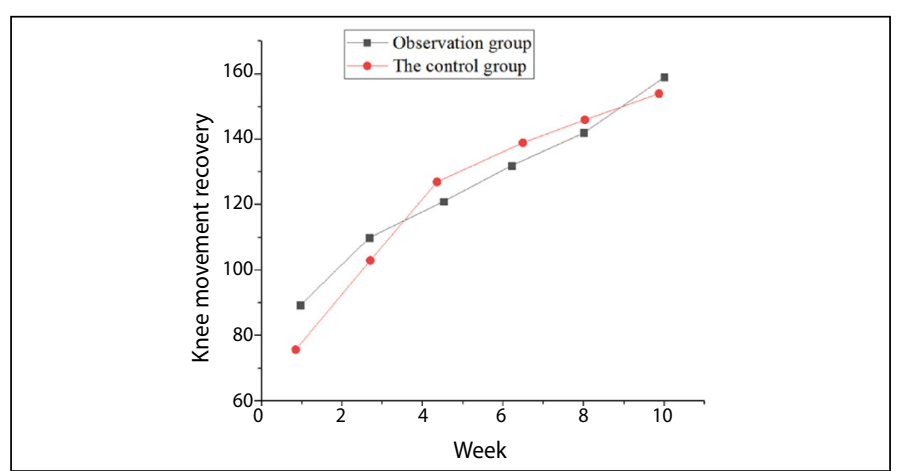

Figure 1. Changes in blood pressure before and after the exercise prescription of the exercise group.

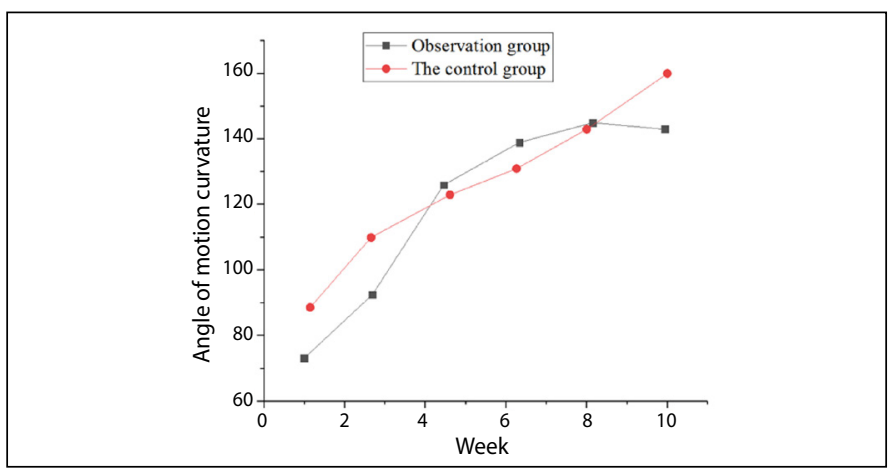

Figure 2. Changes in passive knee flexion angle of affected subjects during rehabilitation. early activity can stimulate the graft for remodeling, without affecting the stability of the joint and restoring the function of the original joint in advance. Muscle strength training, such as knee extension caused by quadriceps muscle contraction alone, simultaneously causes tibia to move forward, thereby increasing the tension of statically stable structure, pulling ACL graft, and increasing tibiofemoral joint stress. Therefore, the early postoperative hip, knee and ankle joints should be active at the same time, and the antagonistic muscle groups of joints should contract cooperatively to simulate the normal joint activity mode, without causing the movement of tibial condyle, and the muscle strength training effect of quadriceps femoris and diaphragmatic cord muscle is significantly improved. ${ }^{10}$ Therefore, it is very important to give early comprehensive rehabilitation training to patients after surgery. Anterior cruciate ligament injury of knee joint after ligament reconstruction, microcirculation was affected by vascular injury, dilation, hyperemia and formation of micro-thrombs, and local inflammatory infiltration, the colloid osmotic pressure between the tissues around the injury site increases, and it is easy to form edema, at the same time, edema and inflammatory substances will stimulate the peripheral nerve to produce pain, affecting the postoperative rehabilitation exercise of patients. The results of this study showed that VAS score of the observation group was significantly lower than that of the control group three days after surgery. Lysholm knee score and knee flexion and extension were significantly higher than those in the control group.

\section{CONCLUSION}

This is because early rehabilitation training is the key to maintaining joint stability after ligament reconstruction. Cold therapy and wax therapy immediately after surgery can not only shrink blood vessels and reduce the permeability of blood vessel wall, it can also reduce the conduction of pain signals. In the case of edema and pain relief in patients, electroacupuncture, acupuncture therapy and massage can dredge the meridians, improve the effect of rehabilitation exercise, and promote the recovery of patients'knee joints. In conclusion, early comprehensive rehabilitation training can improve the knee function score and reduce the pain score of patients after anterior cruciate ligament reconstruction, and its effect is better than that of conventional rehabilitation training.

All authors declare no potential conflict of interest related to this article

AUTHORS' CONTRIBUTIONS: Each author made significant individual contributions to this manuscript. Chuan Shu: writing and performing surgeries; Liming Han: data analysis and performing surgeries; Haochuan Yang: article review and intellectual concept of the article.

\section{REFERENCES}

1. Zhou Y, Feng Q. Effects of rehabilitation exercise on muscle group working characteristics of adolescent patients with scoliosis: 1004 board \#130 may 27 1:30 pm - 3:00 pm. Medicine \& Science in Sports \& Exercise. 2020;52(Suppl 7):252.

2. Grindem $\mathrm{H}$, Arundale AJ, Ardern CL. Alarming underutilisation of rehabilitation in athletes with anterior cruciate ligament reconstruction: four ways to change the game. British Journal of Sports Medicine. 2018;52(18):1162-3.

3. Zdansky E. The effect of balance training on postural control in patients with parkinson's disease using a virtual rehabilitation system. Methods of Information in Medicine. 2017;56(2):138-44.

4. Zhou X, Deng H, Shen X, Lei Q. Effect of balance training on falls in patients with osteoporosis: a systematic review and meta-analysis. Journal of Rehabilitation Medicine. 2018;50(7):577-81.

5. Chisati EM, Constantinou D, Lampiao F. Effects of maximal strength training on bone mineral density in people living with hiv and receiving anti-retroviral therapy: a pilot study. BMC Sports Science Medicine and Rehabilitation. 2020;12(67):1-7.
6. Kang GE, Sharafkhaneh A, Bryant MS, Nguyen C, Najafi B. Efficacy of telerehabilitation on exercise capacity and frailty in veterans with chronic pulmonary obstructive disease: 1397 . Medicine \& Science in Sports \& Exercise. 2021;53(Suppl 8):458.

7. Roztorhui M, Perederiy A. Training athletes with disabilities at the stage of sport and rehabilitation training in strength sports. Physical Education Sport and Health Culture in Modern Society. 2018;1(41):61-6.

8. Tang $X$. The effect of multi-supportive nursing on the postoperative rehabilitation of breast cancer patients. American Journal of Translational Research. 2021;13(6):7327-34.

9. Min K, Beom J, Bo RK, Sang YL, Lim JY. Clinical practice guideline for postoperative rehabilitation in older patients with hip fractures. Annals of Rehabilitation Medicine. 2021;45(3):225-59.

10. Su HC, Shen YJ, Lin GW. Attitudes of prostate cancer patients towards postoperative penile rehabilitation and their influencing factors. Zhonghua nan ke xue = National journal of andrology. 2019;25(5):329-32 